\title{
Technical contribution
}

\section{Length-weight relationships of 26 fish species from the middle section of the Negro River (Tacuarembó-Durazno, Uruguay)}

\author{
By F. Teixeira-de Mello ${ }^{1}$, I. Gonzalez-Bergonzoni ${ }^{1,2}$, F. Viana ${ }^{2}$ and C. Saizar ${ }^{2}$ \\ ${ }^{1}$ Grupo de Ecología y Rehabilitación de Sistemas Acuáticos, Departamento de Ecología y Evolución, CURE-Facultad de Ciencias, \\ Universidad de la República, Maldonado, Uruguay; ${ }^{2}$ Departamento de Medio Ambiente, Laboratorio Tecnológico del Uruguay \\ (LATU), Montevideo, Uruguay
}

\begin{abstract}
Summary
This study provides data on the length-weight relationship (LWR) for 26 species of neotropical fishes. Specimens were collected between 2008 and 2009 from a dam-enclosed section of the middle Negro River (Uruguay). This study represents the first reference on length-weight relationships for 17 species, and also provides new maximum sizes for eight species.
\end{abstract}

\section{Introduction}

Length-weight relationships (LWR) can be a useful tool in the management of fisheries and environmental monitoring programs in many ways, such as making weight estimations of individual fish based on length and vice versa and calculating a condition index to allow for morphology comparisons of populations from different regions (Petrakis and Stergiou, 1995). It also allows for the study of the ontogenetic allometric changes in fish growth (Teixeira-de Mello et al., 2006) and possible effects from parasites (Teixeira-de Mello and Eguren, 2008). Uruguay has a high diversity of freshwater fish, with some 230 species being reported (Nión et al., 2002). Previous LWR studies involved eight species from the Uruguay River (Teixeira-de Mello et al., 2009a) and 21 from Santa Lucia River (Teixeira-de Mello et al., 2009b). The aim of this work was to estimate LWR of 26 common fish species from the main course of the Negro River.

\section{Materials and methods}

The Negro River is the most important tributary to the lower Uruguay River (La Plata River Basin), and crosses Uruguay from NW to W. The two studied sampling sites are within a dam-enclosed area, between Rincón del Bonete and Baygorria dams, in the middle section of the river. Fishes used for lengthweight relationship estimation were captured during four sampling campaigns between November 2008 and July 2009. Fishes were collected in the framework of a baseline monitoring program commissioned to the Technological Laboratory of Uruguay (LATU) by the Stora Enso company, under Collection Permit No. 424/2008, issued by the National Directorate for Aquatic Resources (DINARA). Sacrificed with an overdose of anesthesia (2-phenoxy-ethanol, $1 \mathrm{ml} \mathrm{L}^{-1}$ ) the fishes were identified using various taxonomic keys available for the various fish families present in the region then measured (to the nearest $0.1 \mathrm{~cm}$ standard length, $S_{\mathrm{L}}$ ) and weighed (to the nearest $0.01 \mathrm{~g}$ total weight, $W_{\mathrm{T}}$ ). Parameters for the equation $W_{\mathrm{T}}=a S_{\mathrm{L}}{ }^{b}$ (Ricker, 1973) were estimated by linear regression, following the logarithmic transformation of the variables $\left(\log _{10} W_{\mathrm{T}}=\log _{10} a+b \log _{10} S_{\mathrm{L}}\right)$. Spelling of all scientific names were checked against the FishBase (Froese and Pauly, 2008). Obvious outliers observed in the log-log curves were excluded from the regression. Voucher specimens were fixed in $10 \%$ formalin and $70 \%$ alcohol, and deposited in the Colección de Zoología de Vertebrados of the Facultad de Ciencias (institutional code ZVC-P).

\section{Results and discussion}

A total of 1836 specimens belonging to 26 fish species corresponding to 15 families from eight orders (Siluriformes, Characiformes, Perciformes, Atheriniformes, Cyprinodontiformes, Pleuronectiformes, Clupeiformes and Gymnotiformes) were used for calculation of the $S_{\mathrm{L}}-W_{\mathrm{T}}$ relationships (Table 1). All regressions were highly significant $(\mathrm{P}<0.0001)$.

The data for Oligosarcus jenynsii, Diapoma terofali, Pimelodella gracilis, Parapimelodus valenciennis, Corydoras paleatus, Rhinelepis strigosa, and Hypostomus commersoni must be applied considering the size ranges analyzed in this study. The ranges used were narrow for these species, as major size ranges can present different LWR (Froese, 2006).

Along the length range analyzed, 17 species presented isometric growth, whereas the other species showed allometric growth (three positive and six negative) (Table 1). Worth highlighting is the case of $P$. valenciennis, a species that showed a high Wt variability for the same SL, revealing many scraggy individuals. This results in a low coefficient of determination $\left(r^{2}\right)$ (Table 1). When compared with the data of the Uruguay River (considering the same size range), $b$ is significantly smaller (Table 2). Given seasonal abundance variation in the Uruguay River it is possible that $P$. valenciennis moves large distances for reproductive and/or feeding purposes, as the dam is an enclosed area, the fish may not be able to completely satisfy their food demands. Several LWR estimated for same species were available from the Uruguay (Teixeira-de Mello et al., 2009a) and Paraná rivers (Benedito-Cecilio et al., 1997). The same size range was used in comparing the data from the Uruguay River. The two species compared in the three different systems (Negro, Uruguay and Paraná) failed to show any significant differences in the slope value $(b)$ of the Uruguay and Negro rivers, but both were different from the species 
Table 1

Length-weight relationship parameters of 26 species from the middle section of the Negro River (Tacuarembó-Durazno, Uruguay)

\begin{tabular}{|c|c|c|c|c|c|c|c|}
\hline \multirow[b]{2}{*}{ Family } & \multirow[b]{2}{*}{ Species } & \multicolumn{3}{|c|}{ Length $(\mathrm{cm})$} & \multicolumn{3}{|l|}{ Relationship parameters } \\
\hline & & Min. & Max. & $\mathrm{n}$ & $a \pm \mathrm{CL} 95 \%$ & $b \pm \mathrm{CL} 95 \%$ & $r^{2}$ \\
\hline \multirow[t]{5}{*}{ Characidae } & Oligosarcus jenynsii & 10.0 & 15.5 & 23 & $0.0058(0.0021-0.0164)$ & $3.38(2.98-3.79)$ & 0.928 o \\
\hline & Oligosarcus oligolepis & 6.0 & 24.0 & 31 & $0.0168(0.0111-0.0254)$ & $2.93(2.78-3.08)$ & 0.980 o \\
\hline & Astyanax alburnus & 1.7 & 6.6 & 235 & $0.0180(0.0167-0.0195)$ & $3.01(2.96-3.07)$ & $0.980 \mathrm{o}$ \\
\hline & Bryconamericus ytu & 1.2 & 9.0 & 940 & $0.0236(0.0224-0.0248)$ & $2.97(2.93-3.01)$ & 0.964 o \\
\hline & Diapoma terofali & 3.7 & 5.5 & 50 & $0.0253(0.0169-0.0378)$ & $2.81(2.54-3.07)$ & $0.900 \mathrm{o}$ \\
\hline Parodontidae & Apareiodon affinis & 6.3 & 14.5 & 80 & $0.0164(0.0114-0.0237)$ & $3.05(2.88-3.21)$ & $0.945 \mathrm{o}$ \\
\hline Curimatidae & Cyphocharax voga & 6.0 & 18.9 & 280 & $0.0238(0.0196-0.0289)$ & $3.08(3.01-3.16)$ & $0.961+$ \\
\hline Heptapteridae & Pimelodella gracilis & 8.6 & 12.0 & 7 & $0.0453(0.0098-0.2097)$ & $2.39(1.74-3.04)$ & $0.913 \mathrm{o}$ \\
\hline \multirow[t]{2}{*}{ Pimelodidae } & Parapimelodus valenciennis & 9.3 & 14.2 & 158 & $0.0332(0.0164-0.0671)$ & $2.53(2.24-2.82)$ & $0.652-$ \\
\hline & Iheringichthys labrosus & 6.3 & 24.5 & 243 & $0.0134(0.0113-0.0160)$ & $2.98(2.92-3.05)$ & 0.969 o \\
\hline Auchenipteridae & Trachelyopterus teaguei & 11.0 & 16.5 & 10 & $0.0145(0.0119-0.0177)$ & $3.13(3.04-3.22)$ & $0.998+$ \\
\hline Callichthyidae & Corydoras paleatus & 3.5 & 6.2 & 178 & $0.0734(0.0587-0.0919)$ & $2.61(2.48-2.75)$ & $0.886-$ \\
\hline \multirow[t]{4}{*}{ Loricariidae } & Rhinelepis strigosa & 24.5 & 48.0 & 74 & $0.2851(0.1013-0.8022)$ & $2.38(2.11-2.66)$ & $0.999-$ \\
\hline & Hypostomus commersoni & 17.5 & 32.0 & 6 & $0.0756(0.0236-0.2426)$ & $2.63(2.26-2.99)$ & $0.980-$ \\
\hline & Loricariichthys melanocheilus & 6.5 & 17.8 & 78 & $0.0064(0.0045-0.0091)$ & $3.02(2.88-3.16)$ & 0.960 o \\
\hline & Loricarichthys anus & 13 & 38.5 & 17 & $0.0026(0.0020-0.0034)$ & $3.37(3.28-3.46)$ & $0.997+$ \\
\hline \multirow[t]{2}{*}{ Atherinopsidae } & Odontesthes humensis & 6.0 & 30.2 & 28 & $0.0099(0.0079-0.0125)$ & $3.06(2.96-3.15)$ & 0.994 o \\
\hline & Odontesthes perugiae & 2.5 & 18.5 & 28 & $0.0070(0.0054-0.0092)$ & $3.08(2.97-3.20)$ & 0.991 o \\
\hline Anablepidae & Jenynsia onca & 2.5 & 5.7 & 15 & $0.0226(0.0161-0.0317)$ & $3.02(2.77-3.27)$ & 0.976 o \\
\hline Sciaenidae & Pachyurus bonariensis & 1.7 & 20.5 & 29 & $0.0257(0.0199-0.0332)$ & $2.86(2.75-2.97)$ & $0.990-$ \\
\hline \multirow{3}{*}{ Cichlidae } & Crenicichla scotti & 9.7 & 22.5 & 7 & $0.0084(0.0030-0.0233)$ & $3.30(2.92-3.67)$ & 0.983 o \\
\hline & Gymnogeophagus gymnogenys & 3.4 & 11.1 & 36 & $0.0419(0.0344-0.0510)$ & $2.85(2.75-2.95)$ & $0.989-$ \\
\hline & Gymnogeophagus tiraparae & 3.6 & 10.2 & 9 & $0.0440(0.0307-0.0631)$ & $2.84(2.66-3.01)$ & 0.993 o \\
\hline Sternopygidae & Eigenmannia virescens & 19.2 & 27.0 & 13 & $0.0014(0.0005-0.0038)$ & $3.03(2.71-3.35)$ & 0.969 o \\
\hline Achiridae & Catathyridium jenynsii & 3.2 & 15.5 & 6 & $0.0407(0.0231-0.0715)$ & $3.01(2.74-3.28)$ & $0.992 \mathrm{o}$ \\
\hline Clupeidae & Platanichthys platana & 2.3 & 4.1 & 9 & $0.0147(0.0086-0.0251)$ & $3.06(2.59-3.52)$ & 0.959 o \\
\hline
\end{tabular}

$\mathrm{n}$, number of specimens in analyses and representative of abundance of each species in the study system; max, maximum; min, minimum; $a$, intercept of the relationship; $b$, slope of the relationship; $b \pm 95 \%$ confidence limit level $(\mathrm{SE} * 1.96) ; r^{2}$, coefficient of determination. Bold $=$ new maximum lengths and new length-weight relationships. O, isometric growth; + , allometric positive; -, allometric negative.

Table 2

Length (cm)-weight $(\mathrm{g})$ relationship parameters. $W=a L^{b}$ (after logarithmic transformation of variables) from Paraná River Itaipu Reservoir, Brazil (Benedito-Cecilio et al., 1997), Uruguay River, Uruguay (Teixeira-de Mello et al., 2009a) and Negro River (present work)

\begin{tabular}{|c|c|c|c|c|c|c|}
\hline Species & River & SL range $(\mathrm{cm})$ & $\mathrm{n}$ & $b \pm \mathrm{CL} 95 \%$ & $r^{2}$ & $T$ test \\
\hline \multirow[t]{3}{*}{ Apareiodon affinis } & Negro & $6.3-14.5$ & 80 & $3.05(2.88-3.21)$ & 0.945 & a \\
\hline & Uruguay & $7.1-12.2$ & 70 & $3.06(2.88-3.21)$ & 0.948 & a \\
\hline & Paraná & $7.4-13.5$ & 164 & $2.42(2.24-2.60)$ & 0.810 & $\mathrm{~b}$ \\
\hline \multirow[t]{2}{*}{ Parapimelodus valenciennis } & Negro & $9.3-14.2$ & 158 & $2.53(2.24-2.82)$ & 0.652 & $\mathrm{a}$ \\
\hline & Uruguay* & $9.3-14.2$ & 68 & $3.25(3.18-3.32)$ & 0.963 & $\mathrm{~b}$ \\
\hline \multirow[t]{3}{*}{ Iheringichthys labrosus } & Negro & $6.3-24.5$ & 243 & $2.98(2.92-3.05)$ & 0.969 & $\mathrm{a}$ \\
\hline & Uruguay & $6.4-24.5$ & 1296 & $3.08(3.06-3.10)$ & 0.990 & a \\
\hline & Paraná & $7.3-26.2$ & 3215 & 3.23 & 0.970 & $\mathrm{~b}$ \\
\hline \multirow[t]{2}{*}{ Loricariichthys melanocheilus } & Negro & $6.5-17.8$ & 78 & $3.02(2.88-3.16)$ & 0.960 & $\mathrm{a}$ \\
\hline & Uruguay* & $7.3-20.0$ & 27 & $3.44(3.38-3.50)$ & 0.997 & $\mathrm{~b}$ \\
\hline \multirow[t]{2}{*}{ Pachyurus bonariensis } & Negro* & $5.7-20.5$ & 27 & $2.98(2.90-3.06)$ & 0.990 & $\mathrm{a}$ \\
\hline & Uruguay & $5.0-18.3$ & 458 & $3.05(3.02-3.08)$ & 0.989 & $\mathrm{a}$ \\
\hline \multirow[t]{2}{*}{ Eigenmannia virescens } & Negro & $19.2-27.0$ & 13 & $3.03(2.71-3.35)$ & 0.969 & a \\
\hline & Paraná & $12.7-37.5$ & 124 & $2.45(2.31-2.59)$ & 0.900 & $\mathrm{~b}$ \\
\hline \multirow[t]{2}{*}{ Catathyridium jenynsii } & Negro & $3.2-15.5$ & 6 & $3.01(2.74-3.28)$ & 0.992 & $\mathrm{a}$ \\
\hline & Paraná & $5.5-25.0$ & 57 & $3.09(2.97-3.21)$ & 0.980 & $\mathrm{a}$ \\
\hline
\end{tabular}

$\mathrm{SL}$, standard length; $\mathrm{n}$, number of specimens in analyses; $b \pm 95 \%$ confidence limit level (SE*1.96); $r^{2}$, coefficient of determination; $T$-test, comparisons of same species within different systems; different letters, significant differences; same letters, no significant differences.

Equations re-calculated for same size ranges (max. possible) between Negro and Uruguay rivers, ${ }^{*}$ Re-calculated data.

inhabiting the Paraná River (Table 2). Additionally, Eigenmannia virescens and Loricariichthys melanocheilus presented differences between the Negro and Parana rivers, and between the Negro and Uruguay rivers, respectively. This may be due to the different regional factors that characterize those ecosystems, however, it is necessary to consider that sampling occurred at different times of the year, which may also have affected the $b$ values (Froese, 2006).

This study represents the first reference on LWR for 17 species and shows new records of maximum size for eight species (Table 1), it also increases the number to a total of 40 species LWR relationships analyzed for the country, based on the data available in FishBase (Froese and Pauly, 2008).

\section{Acknowledgements}

We express our sincere thanks to the Stora Enso company for permitting the use of information obtained in the environmental study conducted in the study area. Likewise, we thank Ruben Canavese Siré and Agustín Carnikian 
González for their very helpful field assistance, and Juan M. Clemente for valuable assistance in the organization of the samplings campaigns. We wish to acknowledge the instrumental support provided by the Coast Guard authorities and the staff of Rincón del Bonete for the navigation services. Finally, we thank Harald Rosenthal and the anonymous referees for their comments, which greatly improved this manuscript.

\section{References}

Benedito-Cecilio, E.; Agostinho, A. A.; Velho, R. C. C.-M., 1997: Length-weight relationship of fishes caught in the Itaipu Reservoir, Paraná, Brazil. Naga ICLARM Q. 20, 57-61.

Froese, R., 2006: Cube law, condition factor and weight-length relationships: history, meta-analysis and recommendations. J. Appl. Ichthyol. 22, 241-253.

Froese, R.; Pauly, D. 2008: FishBase. Available at: http://www.fishbase. org (version $01 / 2008$ )

Nión, H.; Ríos, C.; Meneses, P. 2002: Peces del Uruguay. Lista Sistemática y nombres comunes. DINARA-INFOPESCA, Montevideo, pp. 105

Petrakis, G.; Stergiou, K. I., 1995: Weight-length relationships for 33 fish species in Greek waters. Fish. Res. 21, 465-469.
Ricker, W. E., 1973: Linear regressions in fishery research. J. Fish. Res. Board Can. 30, 409-434.

Teixeira-de Mello, F.; Eguren, G., 2008: Prevalence and intensity of black-spot disease in fish community from Cañada del Dragón stream (Montevideo, Uruguay). Limnetica, 27, 251-258.

Teixeira-de Mello, F.; Iglesias, C.; Borthagaray, A. I.; Mazzeo, N.; Vilches, J.; Larrea, D.; Ballabio, R., 2006: Onthogenic allometric coefficient changes. Implicances of diet shift and morphometric attributes in Hoplias malabaricus (Bloch) (Characiforme, Erythrinidae). J. Fish Biol. 69, 1770-1778.

Teixeira-de Mello, F.; Vidal, N.; Gonzalez-Bergonzoni, I.; Iglesias, C., 2009a: Length-weight relationship of eight fish species from the lower section of the Uruguay River (Río Negro, Uruguay). J. Appl. Ichthyol. 25, 128-129.

Teixeira-de Mello, F.; Vidal, N.; Eguren, G.; Loureiro, M., 2009b: Length-weight relationships of 21 fish species from the lower section of the Santa Lucía River basin (Canelones-Montevideo, Uruguay). J. Appl. Ichthyol. 25, 491-492.

Author's address: F. Teixeira-de Mello, Grupo de Ecología y Rehabilitación de Sistemas Acuáticos, Departamento de Ecología y Evolución, CURE-Facultad de Ciencias, Universidad de la República, Maldonado, Uruguay. E-mail: frantei@fcien.edu.uy 